\title{
Prevalence of exercise-induced bronchial lability in families of children with asthma
}

\author{
PETER KÖNIG and SIMON GODFREY \\ From the Department of Paediatrics, Cardiothoracic Institute and Brompton Hospital, Fulham Road, London
}

\begin{abstract}
König, P., and Godfrey, S. (1973). Archives of Disease in Childhood, 48, 513. Prevalence of exercise-induced bronchial lability in families of children with asthma. Exercise tests and skin tests were performed in 65 members of the families of 12 children with asthma. A positive response to skin and exercise challenge frequently, but not invariably, occurred together.

Abnormal exercise-induced bronchial lability was found in 33\% of relatives with a past history of asthma, in $40 \%$ of those with hay fever, and in $32 \%$ of the clinically healthy relatives. The subjects with active asthma chiefly had a tendency to bronchoconstriction, while the other labile subjects chiefly had a tendency to bronchodilatation.

The total proportion of all subjects affected by clinically evident atopic diseases, positive skin tests, or increased bronchial lability was $85 \%$. The importance of using a challenge test to detect a hidden tendency for asthma in family studies is discussed.
\end{abstract}

A high incidence of atopic disease, and particularly asthma, has frequently been reported in families of patients with asthma (Adkinson, 1920; Cooke and Vander Veer, 1916; Spain and Cooke, 1924; Schwartz, 1952; Van Arsdel and Motulsky, 1959; Leigh and Marley, 1967). In some of these studies comparisons were made between the families of asthmatic patients and the families of subjects not suffering from asthma, from the point of view of clinically manifest asthma or other atopic diseases. In another approach, Parker, Bilbo, and Reed (1965) used inhalation of methacholine to show that some asymptomatic sibs of patients with asthma could develop abnormal bronchoconstriction.

It is now well established that asthmatic patients develop bronchoconstriction after running, even if they are asymptomatic at the time (Jones, Buston, and Wharton, 1962; Jones and Jones, 1966; Connolly and Godfrey, 1970). In addition, this type of exercise-induced bronchial lability has been found in children who suffered from wheezy bronchitis in the past but did not develop clinical asthma (König, Godfrey, and Abrahamov, 1972). It was therefore decided to study the families of asthmatic children to see if there was an abnormal incidence of bronchial lability among the relatives.

Received 4 December 1972.

\section{Subjects and methods}

The propositi were 12 unrelated children suffering from asthma as defined by Scadding (1966), who were attending the Paediatric Asthma Clinic of this hospital. The members of their 12 families were studied, including the propositi themselves and their first-degree relatives (parents and sibs). The total number of subjects was 65 , but this did not include all possible subjects because 8 adults and 1 child were either unable or unwilling to attend for investigation. This meant that $88 \%$ of all members of the 12 families were studied, but 4 out of the 9 subjects who were not studied were known to have active asthma from previous records. The subjects were classified in groups as listed in Table I, which were based on the replies to a standard questionnaire about atopic diseases in the subject and his family. A subject was considered healthy if he gave no history, after careful, detailed questioning to supplement the replies in his questionnaire, of having suffered from wheezing or any atopic diseases at any time in his life. If the subject admitted to more than one condition, the most recently active was used for the classification.

Allergic investigation was carried out by prick tests with 24 common allergens in every subject.

The exercise test consisted of continuous running for 6 minutes on a treadmill at a speed and slope which would result in a heart rate of about 170 beats per minute (Connolly and Godfrey, 1970). Peak expiratory flow rate (PEF) was measured with a Wright Peak Flow Meter before, during, and for 15 minutes after the 
Prevalence of abnormal bronchial lability and positive skin tests in different groups

\begin{tabular}{|c|c|c|c|c|c|}
\hline & No. & $\begin{array}{l}\text { Normal } \\
\text { lability }\end{array}$ & $\begin{array}{l}\text { Abnormal } \\
\text { lability }\end{array}$ & $\begin{array}{l}\text { Skin test } \\
\text { negative }\end{array}$ & $\begin{array}{l}\text { Skin test } \\
\text { positive }\end{array}$ \\
\hline $\begin{array}{l}\text { Propositi } \\
\text { Total relatives } \\
\text { Relatives with } \\
\text { active asthma } \\
\text { Relatives with past } \\
\text { history of asthma } \\
\text { Relatives with hay } \\
\text { fever } \\
\text { Relatives with eczema } \\
\text { Healthy relatives }\end{array}$ & $\begin{array}{r}12 \\
53 \\
8 \\
6 \\
10 \\
4 \\
25\end{array}$ & $\begin{array}{l}2(17) \\
35(66) \\
4(50) \\
4(67) \\
6(60) \\
4(100) \\
17(68)\end{array}$ & $\begin{array}{l}10(83) \\
18(34) \\
4(50) \\
3(33) \\
4(40) \\
0(0) \\
8(32)\end{array}$ & $\begin{array}{c}0(0) \\
21(40) \\
1(12) \\
1(17) \\
1(10) \\
3(75) \\
15(60)\end{array}$ & $\begin{array}{l}12(100) \\
32(60) \\
7(88) \\
5(83) \\
9(90) \\
1(25) \\
10(40)\end{array}$ \\
\hline Total subjects & 65 & $37(57)$ & $28(43)$ & $21(32)$ & $44(68)$ \\
\hline
\end{tabular}

Note: Percentage in parentheses.

running. At that stage, a bronchodilator aerosol (salbutamol) was given and a further one-minute run was performed to produce maximum bronchodilatation. The expected values for the PEF were taken from Godfrey, Kamburoff, and Nairn (1970) for children and from Cotes (1968) for adults. The following indices were calculated.

$$
\begin{array}{ll}
\begin{array}{ll}
\text { Resting PEF \% } \\
\% \text { Rise }
\end{array} & \begin{array}{l}
\text { Initial PEF } \\
\text { Expected PEF }
\end{array} \times 100 \\
\% \text { Fall } & \begin{array}{l}
\text { Highest PEF during exercise }- \text { Initial PEF } \\
\text { Initial PEF }
\end{array} 100 \\
\text { Exercise Lability Index (ELI) } & =\frac{\text { Initial PEF }- \text { Lowest PEF after exercise }}{\text { Initial PEF }} \times 100 \\
\text { Jones Lability Index (JLI, Jones, 1966) } & =\frac{\text { Highest PEF during exercise or after bronchodilator }- \text { Lowest PEF }}{\text { Expected PEF }} \times 100
\end{array}
$$

The upper limit of normal (mean +2 SD) for the indices was taken from the work of Silverman and Anderson (1972). The bronchial lability was considered abnormal if either the Jones Lability Index or the Exercise Lability Index was above $22 \%$.

\section{Results}

A high incidence of abnormality was found in the relatives, and one family tree is illustrated in Fig. 1. In fact, in those 7 families where both parents were studied, skin tests were positive in $50 \%$ of parents and $81 \%$ of children, while exercise tests were positive in $36 \%$ of parents and $59 \%$ of children.

Evidence of atopy as judged by positive skin tests was found in $68 \%$ of all the subjects (Table I). All the asthmatic propositi had at least one skin test positive and almost every one had positive tests to more than two allergens. Of the 53 relatives

studied, $15 \%$ were actively asthmatic and of these $88 \%$ had at least one skin test positive. Another $11 \%$ of relatives had a history of asthma in the past and of these $83 \%$ had positive skin tests. In the group of relatives with hay fever or allergic rhinitis (19\% of the total relatives) skin tests were positive in

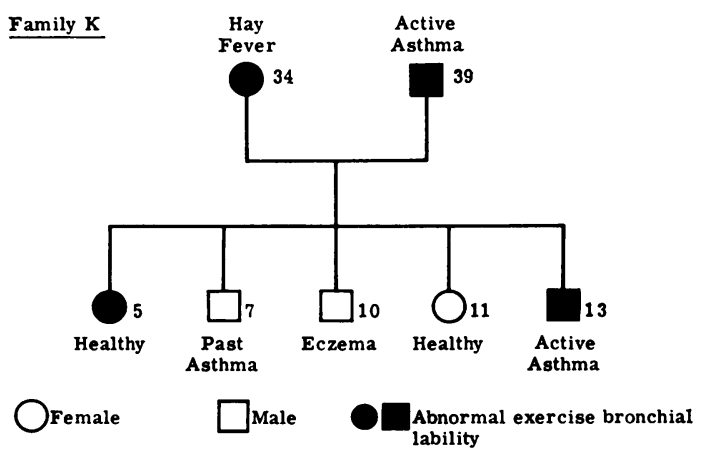

FIG. 1.-Prevalence of clinical atopic disease plus exerciseinduced bronchial lability in the $K$ family. (Numbers give the ages in years.)
TABLE I 
TABLE II

Mean values for exercise lability and average number of positive skin tests per subject in different groups

\begin{tabular}{|c|c|c|c|c|c|c|c|}
\hline & & $\begin{array}{l}\text { Resting } \\
\text { PEF (\%) }\end{array}$ & $\%$ Rise & $\%$ Fall & $\begin{array}{c}\text { Exercise } \\
\text { Lability } \\
\text { Index }\end{array}$ & $\begin{array}{c}\text { Jones } \\
\text { Lability } \\
\text { Index }\end{array}$ & $\begin{array}{c}\text { No. of } \\
\text { positive } \\
\text { skin tests per } \\
\text { subject }\end{array}$ \\
\hline $\begin{array}{l}\text { Propositi } \\
\text { no. }=12 \\
\text { All relatives } \\
\text { no. }=53 \\
\text { Relatives with } \\
\text { active asthma } \\
\text { no. }=8 \\
\text { Relatives with } \\
\text { past history of } \\
\text { asthma } \\
\text { no. }=6 \\
\text { Relatives with } \\
\text { hay fever } \\
\text { no. }=10 \\
\text { Relatives with } \\
\text { eczema } \\
\text { no. }=4 \\
\text { Healthy relatives } \\
\text { no. }=25\end{array}$ & $\begin{array}{l}\text { Mean } \\
\text { SEM } \\
\text { Mean } \\
\text { SEM } \\
\text { Mean } \\
\text { SEM } \\
\\
\text { Mean } \\
\text { SEM } \\
\text { Mean } \\
\text { SEM } \\
\text { Mean } \\
\text { SEM } \\
\text { Mean } \\
\text { SEM }\end{array}$ & $\begin{array}{r}82 \\
6 \\
97 \\
2 \\
90 \\
6 \\
\\
89 \\
8 \\
107 \\
3 \\
103 \\
3 \\
97 \\
2\end{array}$ & $\begin{array}{r}17 \\
4 \\
11 \\
1 \\
15 \\
3 \\
\\
10 \\
3 \\
13 \\
2 \\
7 \\
2 \\
10 \\
2\end{array}$ & $\begin{array}{r}39 \\
6 \\
8 \\
1 \\
18 \\
6 \\
\\
7 \\
3 \\
8 \\
3 \\
4 \\
2 \\
7 \\
1\end{array}$ & $\begin{array}{r}55 \\
7 \\
20 \\
7 \\
33 \\
6 \\
\\
17 \\
4 \\
21 \\
3 \\
12 \\
1 \\
17 \\
2\end{array}$ & $\begin{array}{r}44 \\
5 \\
20 \\
1 \\
30 \\
5 \\
\\
16 \\
3 \\
22 \\
2 \\
13 \\
2 \\
17 \\
2\end{array}$ & $\begin{array}{l}4.8 \\
0.7 \\
1.9 \\
0.3 \\
3.8 \\
0.8 \\
\\
\\
3.2 \\
0.9 \\
\\
3.7 \\
0.9 \\
0.3 \\
0.3 \\
0.6 \\
0.2\end{array}$ \\
\hline
\end{tabular}

$90 \%$ of cases, and in the relatives with eczema $(8 \%$ of the total relatives) skin tests were positive in $25 \%$ of cases.

There were $47 \%$ of the total relatives who were unaffected by asthma or atopic symptoms and skin tests were positive in $40 \%$ of these subjects. The number of positive skin tests on average per subject was significantly lower in the healthy relatives and in those with eczema than in the other groups (Table II).

Evidence of abnormal bronchial lability as judged by a positive exercise test was found in $43 \%$ of all the subjects (Table I). The highest incidence of abnormal lability was found in the asthmatic group (70\% of the combined propositi and actively asthmatic relatives), but there was a very significant incidence among relatives with a past history of asthma (33\%), hay fever ( $40 \%)$, and even among the healthy relatives ( $32 \%)$, but not in the relatives with eczema, though there were only 4 subjects in this group.

The exercise-induced bronchial lability of the propositi was much more severe than that of the relatives with active asthma (Table II). The difference between the ELI for the two groups was highly significant $(0.005>P>0.001)$.

Likewise, the relatives with active asthma had a higher mean lability than those with a history of asthma $(0.05>P>0.025)$, but there was no difference between the mean lability of the relatives with a history of asthma and either those with hay fever or the healthy relatives. The group of relatives with eczema alone had a normal response to exercise, but the number of subjects was too small to draw meaningful conclusions.

The results in the present group of healthy relatives can be compared with those from groups of normal children and adults studied in this department (Anderson, 1972; Silverman and Anderson, 1972). The present group of healthy children (not evidently asthmatic or atopic) had a higher mean ELI $(0.01>\mathrm{P}>0.005)$ and JLI $(0.02>\mathrm{P}>0.05)$ than the other normal group; for the adults, the difference between the present group and the other normal adults was not significant either for the ELI $(0 \cdot 2>P>0 \cdot 1)$ or for the JLI $(0 \cdot 1>P>0 \cdot 05)$.

A further analysis was made of the response to exercise in those subjects with an abnormal total

TABLE III

Sex distribution of positive skin tests and exercise results

\begin{tabular}{|c|c|c|}
\hline & Male & Female \\
\hline $\begin{array}{l}\text { Skin tests } \\
\text { All negative } \\
1 \text { positive } \\
2 \text { positive } \\
\text { More than } 2 \\
\text { positive }\end{array}$ & $\begin{array}{r}9 \\
7 \\
2 \\
20\end{array}$ & $\begin{array}{r}12 \\
3 \\
5 \\
7\end{array}$ \\
\hline Total & 38 & 27 \\
\hline $\begin{array}{c}\text { Exercise lability } \\
<22 \% \\
22-40 \% \\
>40 \%\end{array}$ & $\begin{array}{r}20 \\
7 \\
11\end{array}$ & $\begin{array}{r}17 \\
9 \\
1\end{array}$ \\
\hline Total & 38 & 27 \\
\hline
\end{tabular}




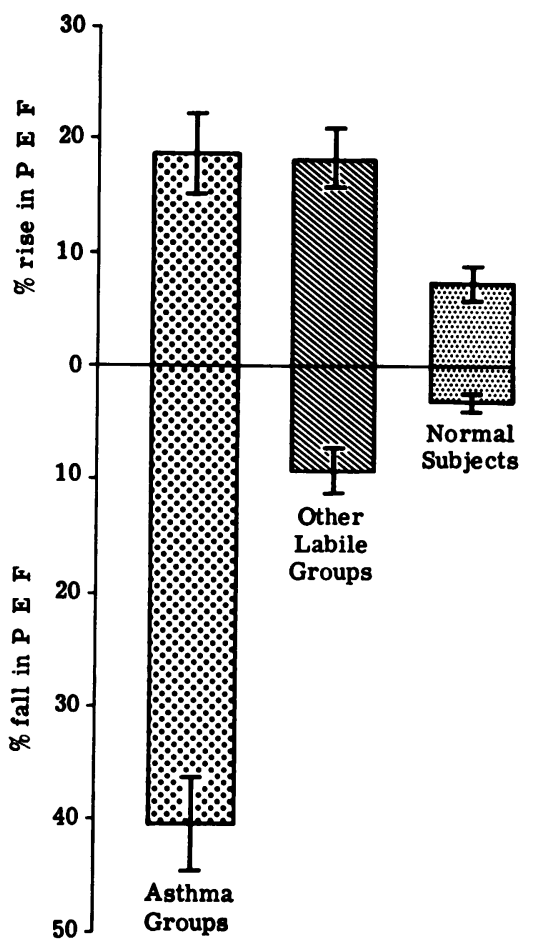

FIG. 2.-Patterns of exercise lability in subjects with an abnormal response to exercise.

lability (i.e. $>22 \%$ ). It was found that the lability in the subjects with active asthma (propositi and relatives) was due mainly to the fall in PEF after exercise, while in the other labile subjects it was mainly due to bronchodilatation during exercise or after a bronchodilator (Fig. 2, Table II). Thus the $\%$ Rise was equal or bigger than \% Fall in only $36 \%$ of the active asthmatics, but in $71 \%$ of the other labile subjects.

The sex distribution of positive skin tests and exercise results is given in Table III. Males heavily predominated in the groups with multiple positive skin tests and high exercise-induced bronchial lability. The relation between skin testing and exercise lability is shown in Table IV.

The abnormal exercise lability was accompanied by at least one positive skin test in $75 \%$ of subjects, but in 7 subjects with abnormal exercise lability the skin tests were negative. From the opposite point of view, among the subjects with positive skin tests, $48 \%$ had an abnormal bronchial lability.

\section{Discussion}

This study has shown that an abnormal exerciseinduced bronchial lability can be found in a high
TABLE IV

Relation between skin testing and exercise lability

\begin{tabular}{l|c|c}
\hline & $\begin{array}{c}\text { Skin test* } \\
\text { positive }\end{array}$ & $\begin{array}{c}\text { Skin test } \\
\text { negative }\end{array}$ \\
\hline $\begin{array}{c}\text { Exerciset } \\
\text { positive }\end{array}$ & 21 & 7 \\
\hline $\begin{array}{c}\text { Exercise } \\
\text { negative }\end{array}$ & 23 & 14 \\
\hline
\end{tabular}

*At least one skin test positive.

tExercise lability or lability index $>22 \%$.

proportion of first-degree relatives of asthmatic children.

The fact that some subjects with a history of asthma or wheezy bronchitis in the past still have abnormal responses to exercise has been noted in other studies (Jones and Jones, 1966; Blackhall, 1970; König et al., 1972). The proportion of abnormal responses in subjects with hay fever in this study $(40 \%)$ compares very closely with the results of Jones (1966) who found such responses in 6 out of 13 cases (46\%).

The most striking finding of the present study was that $32 \%$ of apparently healthy relatives had an increased exercise lability. Parker et al. (1965), using a methacholine challenge test, found an asthmatic response in only $16 \%$ of the healthy sibs and they also found a much lower proportion (10\%) of abnormal responses in patients with hay fever. In their study, $90 \%$ of the children and all of the adults with asthma had an asthmatic response.

The fact that only $70 \%$ of the asthmatics in our study had a pathological lability is in accordance with the results of Silverman and Anderson (1972) who found that on a single exercise test on the treadmill about $75 \%$ of known asthmatics give positive results. This percentage can be increased to between 90 to $100 \%$ by repeating the treadmill exercise on another occasion, and particularly by using free range rather than uphill treadmill running.

Two of the asthmatics in the present study, who on this occasion had normal responses to exercise, had previously responded with abnormal lability. These results were not included in the present study, because tests were not repeated on other members of family.

One of the interesting findings of the present study was that in cases with a pathological bronchial lability the \% Rise was equal to or larger than the \% Fall in most subjects without active asthma, while in active asthmatics the \% Fall was greater in most cases. This pattern of bronchial lability was very similar to the finding of König et al. (1972) who 
compared a group of children with active asthma with a group of children with a past history of wheezy bronchitis, but who had been symptom free for several years. In this study the \% Rise was larger than the $\%$ Fall in $78 \%$ of the subjects with a past history of wheezy bronchitis, but in only $48 \%$ of subjects with asthma. A rather similar pattern of more dilatation than constriction was recently found in a group of children with cystic fibrosis studied by Day and Mearns (1973). Thus, though the nonasthmatic subject may have labile bronchi, it appears to be mainly an ability to dilate and not to constrict. Since resting PEF values of $90 \%$ or so are unlikely to be associated with symptoms, such patients do not have clinical asthma.

The results of the present study could be interpreted as giving support to the hypothesis that bronchial lability is an inherited characteristic which must combine with a triggering mechanism to result in clinical asthma. There was clearly a high incidence of lability among the members of the families of the asthmatics, but only those subjects whose lability was manifest predominantly by constriction had clinical asthma. We have no definite evidence on the nature of the triggering mechanism which caused these subjects to constrict, but one obvious suggestion is IgE-mediated allergy. This need not be the case with every patient because the asthmatic type of exercise response is also seen in skin test negative subjects (Silverman and TurnerWarwick, 1972). The fact that even in the families of asthmatics, $60 \%$ of subjects with positive skin tests had normal lability and no asthma, supports the idea that one must inherit more than atopy alone to be an asthmatic. To carry this hypothesis a little further, we might speculate that the bronchoconstrictor element of inherited lability might be temporarily switched on by virus infection in those infants who develop wheezy bronchitis. After recovery, they revert to the less constricting type of lability. Of course, persistent or repeated viral infections could be another mechanism of triggering the constrictor type of lability resulting in childhood asthma.

Whether the subjects with no clinical asthma but with an increased exercise-induced bronchial lability will eventually develop asthma is not known, but an interesting hint was given when a comparison was made with groups of normal adults and children selected from the population at large. The fact that the present group of healthy childhood relatives of asthmatics had a significantly higher lability than the general population of normal children, while in adults the difference was not significant, could mean that by adulthood some of these labile children may develop asthma or hay fever and would no longer be classified as 'healthy'.

The overall incidence of abnormality found in the present study is very high but is similar in some respects to previously published data. Thus, $26 \%$ of first-degree relatives in the present series had asthma compared to $26 \%$ found by Leigh and Marley (1967). Hay fever occurred in $19 \%$ of relatives in the present study and $20 \%$ of those reported by Leigh and Marley (1967). The incidence of wheezing among sibs was higher in the present study ( $58 \%$ ) compared with the $29 \%$ found by Williams and McNicol (1969).

We know of no family studies of bronchial lability shown by exercise testing.

We were unable to study control groups in the present investigation because of the practical difficulties of inducing whole families to exercise. However, there are some data in the literature with which our findings can be compared. Spain and Cooke (1924) found asthma or hay fever in $7 \%$ of their normal control group, while Williams and McNicol (1969) found that $11 \%$ of all children aged 10 years had had some asthmatic episodes. In their control group of normal children $15 \%$ had a history of wheezing in sibs. Likewise, Leigh and Marley (1967) described asthma in 3\% of the first-degree relatives of their control group, hay fever or vasomotor rhinitis in $16 \%$, and eczema in $12 \%$.

The total proportion of clinically evident cases of atopic diseases among the relatives ( $52 \%$ ), together with the number of relatives with an increased bronchial lability but without clinical disease, gave a total of affected relatives of $68 \%$. If those with positive skin tests are included, this rises to $81 \%$, and if the propositi are added, the total proportion of all subjects affected rises to $85 \%$. This incidence of abnormality in the families of asthmatics is much higher than that found in studies based solely on clinically evident diseases.

We thank Miss Tina Andrea for technical assistance.

\section{REFERENCES}

Adkinson, J. (1920). The behaviour of bronchial asthma as an inherited character. Genetics, $5,363$.

Anderson, S. D. (1972). Physiological aspects of exercise induced bronchoconstriction. Ph.D. Thesis, University of London.

Blackhall, M. I. (1970). Ventilatory function in subjects with childhood asthma who have become symptom free. Archives of Disease in Childhood, 45, 363.

Connolly, N., and Godfrey, S. (1970). Assessment of the child with asthma. Fournal of Asthma Research, 8, 31.

Cooke, R. A., and Vander Veer, A., Jr. (1916). Human sensitization. fournal of Immunology, 1, 201.

Cotes, J. E. (1968). Lung Function. Blackwell, Oxford.

Day, G., and Mearns, M. B. (1973). Bronchial lability in cystic fibrosis. Archives of Disease in Childhood, 48, 355. 
Godfrey, S., Kamburoff, P. L., and Nairn, J. R. (1970). Spirometry, lung volumes and airway resistance in normal children aged 5 to 18 years. British fournal of Diseases of the Chest, 64, 15.

Jones, R. H. T., and Jones, R. S. (1966). Ventilatory capacity in young adults with a history of asthma in childhood. British Medical fournal, 2, 976.

Jones, R. S. (1966). Assessment of respiratory function in the asthmatic child. British Medical fournal, 2, 972.

Jones, R. S., Buston, M. H., and Wharton, M. J. (1962). The effect of exercise on ventilatory function in the child with asthma. British fournal of Diseases of the Chest, 56, 78.

König, P., Godfrey, S., and Abrahamov, A. (1972). Exerciseinduced bronchial lability in children with a history of wheezy bronchitis. Archives of Disease in Childhood. 47, 578.

Leigh, D., and Marley, E. (1967). Bronchial Asthma. Pergamon Press, London.

Parker, C. D., Bilbo, R. E., and Reed, C. E. (1965). Methacholine aerosol as test for bronchial asthma. Archives of Internal Medicine, 115, 452.

Scadding, J. G. (1966). Patterns of respiratory insufficiency. Lancet, 1, 701.
Schwartz, M. (1952). Heredity in bronchial asthma. Acto Allergologica, 5, Suppl. 2, 1.

Silverman, M., and Anderson, S. D. (1972). Standardization of exercise tests in asthmatic children. Archives of Disease in Childhood, 47, 882.

Silverman, M., and Turner-Warwick, M. (1972). Exercise induced asthma: response to disodium cromoglycate in skin-test positive and skin-test negative subjects. Clinical Allergy, 2, 137.

Spain, W. C., and Cooke, R. A. (1924). Studies in specific hypersensitiveness. XI. The familial occurrence of hay fever and bronchial asthma. Fournal of Immunology, 9, 521.

Van Arsdel, P. P., Jr., and Motulsky, A. G. (1959). Frequency and hereditability of asthma and allergic rhinitis in college students. Acta Genetica et Statistica Medica, 9, 101.

Williams, H., and McNicol, K. N. (1969). Prevalence, natural history and relationship of wheezy bronchitis and asthma in children. An epidemiological study. British Medical fournal, 4,321 .

Correspondence to Dr. S. Godfrey, Department of Child Health, Hammersmith Hospital, Du Cane Road, London W12. 